\section{Aleksandra Byrska}

Uniwersytet Jagielloński

\title{
Język kobiecy jako złudzenie? Pytania o istnienie narracji uwarunkowanej przez płeć
}

\section{Abstract \\ Feminine Language as a Fancy, or Does Gender-Determined Narration Exist?}

The article asks about the adequacy of the theory of feminine language and| the practice of women writing. It considers the notion of hysteria as not only a feminine phenomenon. It pays attention to examples of women texts, which are not conditioned by gender, and compares examples of women and men prose to show that the characteristics of poetics are still not enough to apprehend the idiosyncrasy of femininity.

Słowa kluczowe: język, narracja, kobiecość, proza, emocje, histeria, męskość

Keywords: language, narration, femininity, prose, emotions, hysteria, masculinity 
Istnieje wiele teorii opisujących język kobiecy jako specyficzny sposób pisania, prowadzenia narracji czy też wypowiadania się w ogóle, od pisania własnym ciałem Hélène Cixous ${ }^{1}$, przez krytykę psychoanalizy Luce Irigaray ${ }^{2}$, po arachnologię Nancy Miller ${ }^{3}$ czy też - na gruncie literaturoznawstwa polskiego - koncepcję Grażyny Borkowskiej, mówiącą o tym, że każdy tekst cielesny jest tekstem kobiecym, co sprawia, że Borkowska klasyfikuje jako „pisarstwo kobiece” także utwory pisane przez mężczyzn ${ }^{4}$. Wszystkie te teorie mówią jednak o języku kobiecym na wysokim poziomie abstrakcji, a nawet zakładają wprost, że jest on nieopisywalny. Czy zatem naprawdę istnieje? Teoretyczki drugiej fali feminizmu wykonały imponującą pracę, która miała na celu zrealizowanie wielkiego marzenia - uprawomocnienia pisarstwa kobiecego, otworzenia dla niego drogi, stworzenia możliwości zamanifestowania się innego sposobu tworzenia niż głównonurtowe, czyli męskie. Czy jednak taka prosta klasyfikacja - podział narracji ze względu na płeć autora - nie okazała się wielkim złudzeniem? Projekt stworzony m.in. przez Cixous zawierał w sobie założenie, że piszące kobiety otworzą się na wyjątkowe warstwy języka, tylko dla nich dostępne i skrajnie odmienne od tych używanych do tej pory zarówno przez kobiety, jak i mężczyzn, miał więc charakter utopijny. W praktyce natomiast bardzo trudno określić, czym jest kobiecość tekstu, a wybitne pisarki niejednokrotnie przekraczają wszelkie teoretyczne założenia. Dlaczego prawo do wypowiadania się poprzez cielesność ma być przypisywane wyłącznie kobietom? W swoim artykule chciałabym rozważyć możliwości praktycznego wykorzystania teorii pisania kobiecego w odniesieniu do istniejących tekstów literackich, wskazać słabe punkty teorii i stracone już złudzenia nieograniczonych możliwości emancypacji językowej, ale także rozważyć, czy język kobiecy rzeczywiście istnieje, czy jest to tylko i wyłącznie kolejna teoretyczna konstrukcja.

Virginia Woolf i Justyna Bargielska, Gabriela Zapolska i Julia Fiedorczuk, Charlotte Brontë i Inga Iwasiów, Colette, Joanna Mueller, Magdalena Tulli, Olga Tokarczuk czy Zofia Nałkowska, Narcyza Żmichowska i Dorota Masłowska - twórczość każdej z nich jest na wskroś kobieca, a równocześnie trudno niejednokrotnie odnaleźć między nimi punkty wspólne. Jak zatem określać pisarstwo kobiet? Czy można stopniować kobiecość prozy albo odmówić kobiecości pisarce? Gdzie szukać i czy szukać na siłę kobiecego języka? W jakim stopniu realizuje się on w praktyce?

${ }^{1}$ Por. H. Cixous, Śmiech meduzy, przeł. A. Nasiłowska „Teksty Drugie” 1993, nr 4-6.

2 Por. L. Irigaray, Ta pleć (jedna) ptcia niebędąca, przeł. S. Królak, Kraków 2010.

${ }^{3}$ Por. N.K. Miller, Arachnologie: kobieta, tekst i krytyka, przeł. K. Kłosińska, K. Kłosiński [w:] Teorie literatury XX wieku. Antologia, red. A. Burzyńska, M.P. Markowski, Kraków 2007.

${ }^{4}$ Por. G. Borkowska, Metafora drożdży. Co to jest literatura/poezja kobieca [w:] Ciało $i$ tekst. Feminizm $w$ literaturoznawstwie - antologia szkiców, red. A. Nasiłowska, Warszawa 2001. 
Pytanie o pisarstwo kobiece od zawsze wywoływało gwałtowne spory, które, gdy już zaakceptowano sam fakt istnienia kobiety pisarki, krystalizowały się wokół dwóch skrajnych postaw, jak choćby w przypadku konfliktu zaistniałego między Ireną Krzywicką a Marią Kuncewiczową po opublikowaniu słynnego Jazgotu niewieściego. Mam wrażenie, że do dziś nie potrafimy wyjść poza zarysowaną tam różnicę stanowisk. Krzywicka pisała:

Rozproszona obecnie w literaturze opisowość, cackanie się z byle głupstwem urasta $z$ przykrego narowu do rozmiarów groźnego nałogu. Choć i mężczyźni nie są bez grzechu, zwłaszcza potomstwo duchowe Kadena, ale celują w tej manierze kobiety. Opisują wszystko: każdą barwę, każdy dźwięk, każdy sprzęt, każdy ruch. Opisują i porównują wszystko do wszystkiego. W pogoni za nową metaforą, za rzadkim zestawieniem wyrazów, zatracają poczucie śmieszności, wpadają w najdzikszy barok. [...] Wyogromnia się niepotrzebne nikomu spostrzeżenia, spiętrza się epitety, pieści się z różnymi głupstewkami zmanierowanych panienek. Przymiotników używa się w stopniu najwyższym, rzeczowników szuka się rzadkich i ważkich, czy zachodzi potrzeba czy nie. Powstaje cały kierunek, taki jakiś z-igły-widły-zm. A jazgocze się przy tym, a siurka, a siorba, a siaka, tyrba i tłamsi! I na dobitkę, jak przystało na literaturę kobiecą, pełno w tych książkach minoderii, histerii, przesady i sztuczności5.

Odpowiedź Kuncewiczowej w artykule Metaforyzm a męskie kasztele brzmiała tak:

Metaforyzm jest koniecznością niektórych stanów twórczych. Jest wykładnikiem pewnej ściśle określonej treści. [...] Charakteryzowany wyżej sensualizm, przemawiający w literaturze językiem metafory, cechuje wiele utworów kobiecych. Zatem niechęć męska do czynnej kobiecości usiłuje nadać temu walorowi zabarwienie pewnej Minderwärtigkeit (niższej wartości) - powlec śmiesznością - unieruchomić. [...] Skoro metaforyzm dał zaszczepić się tak łatwo na twórczości kobiecej - stanowi widocznie wyraz odpowiedni dla specjalnego materiału, jakim ona operuje ${ }^{6}$.

Kuncewiczowa odpiera zatem zarzuty, sugerując, że specyficzny styl pisarstwa kobiecego wynika ze szczególnych stanów wewnętrznych przeżywanych przez kobiety i domagających się wyrażenia, których świat męski nie chce

${ }^{5}$ I. Krzywicka, Jazgot niewieści, czyli przerost stylu [w:] ,, Chamuly”, ,,gnidy”, ,,przemilczacze"... Antologia dwudziestowiecznego pamfletu polskiego, oprac. D. Kozicka, Kraków 2011, s. 382-383.

${ }^{6}$ M. Kuncewiczowa, Metaforyzm a męskie kasztele, „Wiadomości Literackie” 1928, nr 44, s. 1, cyt. za: K. Majbroda, Feministyczna krytyka literatury w Polsce po 1989 roku. Tekst, dyskurs, poznanie z odmiennej perspektywy, Kraków 2012, s. 557-558. 
uznać, a zatem stara się im odmówić wartości i wyśmiać. Obie panie, opisując język piszących kobiet, odwołują się do charakterystyk, które pojawiają się także dziś. Czym bowiem jest język kobiecy według teorii Hélène Cixous, Julii Kristevej czy Luce Irigaray?

Niezależnie od tego, że ich teorie różnią się między sobą we wskazywaniu źródeł języka kobiecego, cechy charakterystyczne dotyczące poetyki écriture feminine, które można wyodrębnić w czasie czytania ich tekstów, okazują się podobne. To przede wszystkim: fragmentaryczność, brak linearności i ciągów przyczynowo-skutkowych, kompulsywność wypowiedzi, emocjonalność i zmysłowość. To również stosowanie powtórzeń i wyliczeń oraz poetyckich ekwiwalentów stanów wewnętrznych. Typowa dla takiej prozy jest też skłonność do dygresji i swobodnych skojarzeń, a także stosowanie w prozie poetyckich tropów. Fabuła często schodzi na drugi plan, a najważniejszy pozostaje narrator i jego emocje; to on, a raczej ona dzieli wydarzenia na ważne i mniej istotne według własnego klucza. Niejednokrotnie to proza skrajnie subiektywna i zorientowana na cielesność.

Przykłady tego typu prozy możemy mnożyć, stopniując wymienione powyżej cechy od ornamentyki Narcyzy Żmichowskiej ${ }^{7}$, przez zorientowanie na ciało i jego histeryczność Gabrieli Zapolskiej ${ }^{8}$, aż po przykłady z literatury najnowszej, takie jak teksty Justyny Bargielskiej, Julii Fiedorczuk czy Sylwii Chutnik (w przypadku tej ostatniej myślę przede wszystkim o Dzidzi) lem jednak w tym, że wszystkie te cechy można nazwać inaczej: somatyzacją przeżyć wewnętrznych, afektywnością, strumieniem świadomości, mimesis życia wewnętrznego, prozą poetycką. Wszystkie one nie są również obce piszącym mężczyznom.

Istotnym problemem $\mathrm{w}$ dyskusji starającej się określić specyfikę narracji uwarunkowanej przez płeć jest również postrzeganie histeryczności i emocjonalności jako cech wyłącznie kobiecych i przypisywanych pisarstwu kobiecemu. Do źródeł takiego sposobu myślenia dotarła Elaine Showalter, badając postrzeganie kobiecej melancholii poprzez recepcję postaci Ofelii:

Traktując sprawę klinicznie, zachowanie i wygląd Ofelii są charakterystycznymi objawami choroby, którą elżbietanie nazwali kobiecą melancholią na tle miłości, czy też erotomanią. Od około 1580 roku melancholia stała się modną chorobą młodych mężczyzn, szczególnie w Londynie, a sam Hamlet jest prototypem bohatera melancholicznego. Jednak epidemia ta kojarzona z geniuszem intelektu i wyobraź-

${ }^{7}$ Por. N. Żmichowska, Poganka, Warszawa 1976.

${ }^{8}$ Por. G. Zapolska, Przedpiekle, Kraków 1957; K. Kłosińska, Ciało, pożadanie, ubranie. O wczesnych powieściach Gabrieli Zapolskiej, Kraków 1999.

${ }^{9}$ Por. J. Bargielska, Obsoletki, Wołowiec 2010; J. Fiedorczuk, Poranek Marii i inne opowiadania, Wrocław 2010; S. Chutnik, Dzidzia, Warszawa 2009. 
nią ,dziwnie omijała kobiety”. Źródła kobiecej melancholii widziano w kobiecej biologii i kobiecych uczuciach ${ }^{10}$.

W ustawianiu pojęcia kobiecej melancholii w opozycji do melancholii męskiej to pierwsze wywodzono z przyczyn biologicznych, to drugie - z intelektualnych. W ten sposób ujawnia się stara binarna opozycja kobieta-ciało/mężczyzna-intelekt, która z dzisiejszej perspektywy wydaje się krzywdząca dla obu stron. Łatwo też zauważyć, że kobieca melancholia jest tutaj po prostu histerią. Showalter pokazuje jednak, że męska histeria również istnieje od zawsze. W tym kontekście ważna i przenikliwa okazuje się obserwacja Jarosława Topolewskiego:

Dla Showalter histeria nie jest metaforą, emblematem, ani wytrychem. Nie jest związana też z istotą kobiecości, co Showalter pokazuje, tropiąc skrywany wątek męskiej histerii. Jest rzeczywistością, która może obrócić się przeciwko feminizmowi, kobietom, mężczyznom, nam wszystkim. Showalter pisze: „[...] My, kobiety cierpimy ciągle na histeryczne symptomy nie dlatego, iż jesteśmy z natury irracjonalne lub wszystkie byłyśmy ofiarami wykorzystywania, lecz dlatego, że jesteśmy istotami ludzkimi, tak samo jak mężczyźni. Istotami, które przekształcają uczucia w symptomy, gdy nie mogą mówić - gdy przerasta je wstyd, wina lub bezsilność"11.

Mitologizacja histerii jako cechy konstytutywnej kobiecości jest poważnym problemem, o którym pisał Paweł Dybel. Sprowadzenie kobiecych zaburzeń psychicznych do tak postrzeganej histeryczności blokuje możliwość ich leczenia, bo ,jak wyleczyć pacjentkę z symptomów histerycznych, skoro właśnie w nich przejawia się najwymowniej to, co czyni ją kobietą?"12. Dybel w swoim artykule zadaje także inne, równie istotne pytania:

Może więc należałoby najpierw zapytać o status i prawdziwość tego utrwalonego w europejskiej tradycji kulturowej przekonania? Może szczególna podatność kobiet na histerię nie ma nic wspólnego z kobiecością jako taką, ale jest jedynie wynikiem ich zmarginalizowanej pozycji w ramach patriarchalnego modelu kultury? Może w tym fakcie nie ma żadnej konieczności, może stanowi on jedynie efekt oddziaływania określonych historycznych uwarunkowań? ${ }^{13}$

${ }^{10}$ E. Showalter, Przedstawiając Ofelię. Kobiety, szaleństwo i zadania krytyki feministycz$n e j$ [w:] Ciało i tekst. Feminizm w literaturoznawstwie - antologia szkiców, red. A. Nasiłowska, Warszawa 2001, s. 194.

11 J. Topolewski, Rozbić triadę. Histeria, kobiecość, feminizm - wedtug Elaine Showalter [w:] Krytyka feministyczna. Siostra teorii i historii literatury, red. G. Borkowska, L. Sikorska, Warszawa 2000, s. 219.

${ }_{12}$ P. Dybel, Histeria - ,inny język” kobiecości?, ,Teksty Drugie” 2006, nr 6, s. 134.

${ }_{13}$ Ibidem. 
Cielesność nie należy wyłącznie do kobiet, podobnie jak emocje. Zaprzeczając tym faktom, wikłamy się w kolejne stopnie wykluczenia. Rezerwując odczuwanie ciałem oraz gwałtowne emocje tylko dla jednej płci i określając kobiecość poprzez zaburzenia, odbieramy jej prawo do pisania obiektywnego, wyważonego emocjonalnie i intelektualnego.

Należy także pamiętać, iż nie wszystkie autorki posługują się w swoich książkach sugerowanym przez teoretyczki językiem kobiecego ciała. Monika Świerkosz w artykule zatytułowanym Arachne i Atena. W strone innej poetyki pisarstwa kobiecego wskazuje na wykluczający charakter dzielenia pisarstwa kobiecego na podstawie języka i posługując się figurami Arachne jako ciała bez głowy i Ateny jako głowy bez ciała, znajduje możliwość innego odczytania postaci Ateny niż tylko jako „męskiej” kobiety. Zauważa przy tym:

Jeśli bogini miała być wcieleniem cnót męskich, dlaczego była jednocześnie największą nauczycielką kobiecych robót i kobiecej sztuki: tkactwa, garncarstwa, gotowania, a także opiekunką rodzących? Pronaja, Ergane, Polias, Promachos, Parthenos, Pallas, Higieja - jakkolwiek nazwana, wymyka się jednoznacznej - i nazwijmy ją patriarchalnej - symbolice. Idąc za badaniami Jane Ellen Harrison, Robert Graves w Mitach greckich pisze wprost o Atenie jako połączeniu dwóch wcieleń matriarchalnej triady boginicznej - budzącej trwogę staruchy i dziewicy ${ }^{14}$.

Dlaczego te rozważania są tak istotne? Bo, jak pisze Świerkosz:

Jest to o tyle interesujący trop, że krytyka feministyczna wciąż boryka się z problemami metodologicznymi: jak czytać te teksty kobiet, które stawiając się po stronie rozumu, a nie ciała, nie realizują uznawanego za kulturowo kobiecy wzorca somatycznego pisania lub też nie są ani pod względem formy, ani treści inne od męskiego sposobu ekspresji? Czy pozbawiony aspektu awangardowości, tradycyjny w swej formie tekst pisarki niepodejmującej tzw. kobiecej, emancypacyjnej tematyki staje się automatycznie tekstem niefeministycznym, tzn. nie-kobiecym, tj. patriarchalnym? Czy autorki klasycyzujące, intelektualnie zdystansowane wobec swojego tekstowego ,ja" lub stawiające nie na autobiografizm, lecz na awangardowy eksperyment, zakłamują swe kobiece doświadczenie, mają problem ze swoją tożsamością, są stłumionymi ofiarami patriarchalnej schizofrenii bądź też zakładają dla kurażu męskie kapelusze, mówiąc nie-swoim głosem? ${ }^{15}$

${ }_{14}$ M. Świerkosz, Arachne i Atena. W stronę innej poetyki pisarstwa kobiecego, „Teksty Drugie" 2015, nr 6, s. 80.

15 Ibidem, s. 81. 
Odmawianie kobiecości całej rzeszy pisarek czy też posądzanie ich o podporządkowanie się patriarchatowi wyłącznie na podstawie poetyki wydaje się niesprawiedliwe i ograniczające. Czy Eliza Orzeszkowa, tworząc Martę ${ }^{16}$, nie napisała tekstu skrajnie kobiecego, a nawet feministycznego pomimo oszczędności stylistycznej? Czy można mówić o realistycznych powieściach Virginii Woolf ${ }^{17}$, że są mało kobiece? Dlaczego jako kobiety mamy odmawiać sobie prawa do rozsądku, dystansu, trzeźwego osądu czy inteligencji?

Najciekawsze przykłady podważające sensowność jednoznacznej językowej klasyfikacji to przemiany w obrębie twórczości jednej osoby, na przykład porównanie wczesnej i późnej twórczości Zofii Nałkowskiej albo Olgi Tokarczuk okazuje się niezwykle interesujące. Obie pisarki na wczesnych etapach swojej twórczości opublikowały teksty stereotypowo kobiece. Wystarczy sięgnąć choćby po Kobiety, debiut Nałkowskiej, i zacytować stamtąd taki na przykład fragment pierwszej części, zatytułowanej Lodowe pola:

Rzuciłam moje niezmierzone lodowe pola, moje zorze polarne i zimne, srebrne sny w stalaktytowych grotach - i wyszłam na spotkanie życia - słoneczna i silna. Witam je śmiechem dzwoniącym, który jest syntezą długich dni męki i daremnego myślenia, skazuję się na nie z rezygnacją, nie z bezsiły zrodzoną, lecz z nadludzkiego wysiłku, poddaję się brutalności jego bez drgnienia wstrętu i buntu. Na gruzach moich marzeń mistycznych wyrósł bujny kwiat, pozytywny, twardy kult życia i rozkoszy. Wspaniałomyślna i królewska jest moja rezygnacja. Kocham życie mimo wszystko. Depcę duszę moją - krwiożerczą, nienasyconą, chmurną duszę, która zabiła mi szczęście. Chcę zerwać dzisiaj czerwony, płomienny kwiat życia. Śpiewem przyzywam fauna ${ }^{18}$.

Bohaterka Nałkowskiej leży na łące i w otoczeniu natury zagłębia się w swoje emocje oraz wrażenia zmysłowe. Sposób wyrażenia przeżyć bohaterki to czysty „metaforyzm” opisywany przez Kuncewiczową. Innym przykładem jest E.E. Olgi Tokarczuk:

Erna zasypiała na brzuchu, z rękami podłożonymi pod siebie. Zasypiając, kołysała w myślach swoje ciało, w jedną i w drugą stronę, w lewo i w prawo, jak w niewidzialnej kołysce. Tym kołysaniem najczulej, jak potrafiła, zajmowała się sobą. Sama stawała się dla siebie matką, potem Bertą, potem kimś potężnym i wielkim, kogo jednak nie potrafiła określić ${ }^{19}$.

16 Por. E. Orzeszkowa, Marta, Warszawa 1953.

${ }_{17}$ Por. V. Woolf, Do latarni morskiej, przeł. K. Klinger, Warszawa 2005; eadem, Pani Dalloway, przeł. K. Tarnowska, Kraków 2016.

${ }_{18}$ Z. Nałkowska, Kobiety, Warszawa 1976, s. 9-10.

${ }^{19}$ O. Tokarczuk, E.E., Wałbrzych 1999, s. 123. 
Ukojenia wobec wstrząsu pierwszej miesiączki Erna szuka w figurach Natury i Matki, dwóch najbardziej podstawowych kobiecych motywów, o których pisała Simone de Beauvoir ${ }^{20}$. Są to przykłady utrzymane jeszcze w stosunkowo stonowanej poetyce, ale wyraźna jest w nich koncentracja na ciele bohaterki i jej wrażeniach zmysłowych. Nałkowska metaforyzuje stany wewnętrzne bohaterki, używając obrazów natury, prowadzi emocjonalny monolog. Tokarczuk z kolei wykorzystuje walory brzmieniowe słów i powtórzenia, a w kolejnych fragmentach, gdy Erna ucieka do lasu, a jej strach koi zmysłowy kontakt z naturą, daje się ponieść typowo „kobiecemu” obrazowaniu.

Nałkowska i Tokarczuk zdecydowały się jednak na przekroczenie języka klasyfikowanego jako kobiecy, ponieważ okazał się dla nich niewystarczający. Obie autorki udowodnily, że potrafią stworzyć klasyczną prozę - myślę, że ani Granica $^{21}$ i Medaliony ${ }^{22}$, ani Księgi Jakubowe $e^{23}$ nie są książkami, które można by posądzić o histeryczność czy subiektywność. Nie można posądzać tych autorek o wybór koniunkturalny, czyli chęć przypodobania się szerszej publiczności. Ich motywacji szukałabym raczej w odrzucaniu ograniczeń i negacji uwarunkowania tekstu przez płeć, które okazały się niezbędne, aby eksplorować nowe możliwości twórcze i nie zamykać się na płaszczyźnie doświadczeń wyłącznie jednego typu.

Podobnym ,przekroczeniem" - z perspektywy stereotypowych przekonań na temat kobiecego pisarstwa - są teksty męskie, które spełniają wyznaczniki języka kobiecego, takie jak somatyczność, histeryczność czy fragmentaryczność. O histeryczności pisarstwa Tadeusza Konwickiego bardzo przekonująco pisała Agnieszka Wróbel w „Tekstach Drugich”:

W Małej apokalipsie główny bohater stwierdza: „histeria to moje paliwo, moje zagłębie energetyczne". Skala jej rozumienia i przedstawiania przez Konwickiego jest szeroka. Ma też ona u niego wyraźnie dwubiegunowy charakter: jest nie tylko słabością, jak wskazywałyby tradycyjne obiegowe konotacje słowa histeria, odsyłające do kobiecej seksualności, ale jest też główną mocą napędową działania bohaterów. W przypadku Konwickiego można wręcz mówić o „pisaniu histerią”, gdyż „histeryczność” wpływa zarówno na konstrukcję bohaterów oraz na sposób kreowania obrazu męskości, jak i na charakter stylu jego prozy, ze znamienną dla niego ekspresyjnością, skłonnością do przesady i hiperboli. Jedną z cech tej histerycznej „poetyki” jest swoisty „,przymus powtarzania” odnotowany w recepcji ${ }^{24}$. 2014.

${ }^{20}$ Por. S. de Beauvoir, Druga płeć, przeł. G. Mycielska, M. Leśniewska, Warszawa

${ }^{21}$ Por. Z. Nałkowska, Granica, Kraków 2007.

22 Por. eadem, Medaliony, Kraków 2008.

${ }^{23}$ Por. O. Tokarczuk, Księgi Jakubowe, Kraków 2014.

${ }^{24}$ A. Wróbel, „Rozhisteryzowany swoja niemoca” - męskość w twórczości Tadeusza Konwickiego (na podstawie ,, Sennika współczesnego”), „Teksty Drugie” 2015, nr 2, s. 338. 
Inne przykłady tego typu nieoczywistej, niewątpliwie męskiej, lecz również histerycznej literatury to twórczość Szczepana Twardocha, Wojciecha Engelkinga czy Michała Witkowskiego ${ }^{25}$. Każdy z nich zasługuje na osobną analizę, ja jednak ograniczę się jedynie do Morfiny Twardocha. To zresztą zaskakujące, do jakiego stopnia Twardoch - kreowany przez media na króla męskiej czy może nawet maczystycznej prozy - jest somatyczny, histeryczny i nielinearny. Justyna Tabaszewska zauważa, że:

[...] narracja, jaką za pomocą Konstantego Willemanna prowadzi Szczepan Twardoch, jest z jednej strony wyraźnie rozdrobniona, porwana, kierowana rytmem skojarzeń, przypomnień i powrotów, z drugiej jednak nie sposób oprzeć się wrażeniu, że jest ona skrajnie refleksyjna. Doznania i przeżycia Konstantego są ciągle w jakiś sposób zmediatyzowane i obrobione, opracowane, nawet wtedy, gdy ma to być chaotyczne zdanie sprawy z tego, co się wydarzyło lub wydarza $^{26}$.

Jednak nawet jeśli ten chaos jest zaplanowany i refleksyjny, to nie można zaprzeczyć jego istnieniu - emocjonalne rozedrganie jest podstawą działania głównego bohatera Konstantego Willemanna. Histeria dobrze opisuje jego kondycję psychofizyczną - Konstanty szarpie się pod wpływem sprzecznych emocji i biernie poddaje wpływowi przypadków, niestabilność jest jego stanem stałym. Taka kreacja bohatera zaprzecza sensowności opozycji binarnych, bo jego zachowania charakteryzują cechy tradycyjnie zarezerwowane dla kobiet - ulega potrzebom ciała, postępuje emocjonalnie, jedyną cechą typowo „męską”, jaką przejawia, jest brak związku z naturą i zdecydowane opowiadanie się po stronie kultury i cywilizacji.

Osobne miejsce w Morfinie zajmują monologi nieokreślonego „głosu”, w którym krytycy ${ }^{27}$ dopatrują się między innymi historii, śmierci, bogini-matki, podświadomości, a nawet kobiecej strony duszy Konstantego. Jeden $\mathrm{z}$ takich monologów brzmi następująco:

${ }_{25}$ Por. S. Twardoch, Morfina, Kraków 2013; W. Engelking, Lekcje anatomii doktora D., Kraków 2016; M. Witkowski, Lubiewo, Kraków 2005.

${ }^{26} \mathrm{~J}$. Tabaszewska, Zepsuty afekt [w:] Ciała zdruzgotane, ciała oporne. Afektywne lektury XX wieku, red. A. Lipszyc, M. Zaleski, Warszawa 2015, s. 282.

27 Przykładowo Justyna Sobolewska w recenzji dla „Polityki” określa głos jako Mojrę, melancholię lub morfinę, http://www.polityka.pl/tygodnikpolityka/kultura/ksiazki/ 1533239,1,recenzja-ksiazki-szczepan-twardoch-morfina.read [dostęp: 13.02.2017]; sam autor w jednym z wywiadów mówił: „- To może być matka, Polska, czarna bogini, śmierć. Ten »ktoś trzeci« z Ziemi jałowej Eliota, przez którą jakoś przyszedł mi do głowy cień, który idzie za Konstantym. W konspekcie zapisałem: »ta, która idzie za mną«. Albo jeszcze jungowska anima, albo Polska, sam nie wiem. Jest w każdym razie na pewno Kostka niewolą, jego kajdanami. Daje mu to taką heglowską świadomość nieszczęśliwą, która go pęta, jest Konstantego niedokonaniem, niedopełnieniem [...]”, http://wyborcza. 
A ja ich widzę, Kosteczku, widzę ich, jak ku światłu świata przeciskają się przez wąskie tunele matczynych łon i jak ze świata przeciskają się przez inne tunele w drugie królestwo śmierci od kuli ze starości od ognia i widzę ich w ruchu nieruchomych i ciebie widzę i ciebie kocham Kosteczku, i chciałabym, tak bardzo chciałabym, żebyście zrozumieli, żebyście wiedzieli wszyscy, że jesteście jako kamienie tego miasta i jako wróble i jako gołębie i jako kamyczki maleńkie w ogromnej, mieniącej się krwią i śmiercią mozaice. Nie ma tu wody, jest tylko skała i żadnej wody i piaszczysta droga i góry i skały i żadnej wody i w drodze nie możecie ustać ani myśleć, pot jest suchy i stopy w piasku zanurzone, taki jest świat, który przemierzam, drugie królestwo śmierci, jestem tą trzecią, która idzie za wami tam, gdzie was tylko dwoje, ja idę za wami, nad wami i w was w suchym królestwie śmierci ponad wami ja i moje senne towarzyszki. Nocni robotnicy ${ }^{28}$.

W tym sposobie kompulsywnego wyrzucania z siebie słów można znaleźć podobieństwa do pisarstwa Justyny Bargielskiej, a zwłaszcza do Obsoletek, w których autorka wielokrotnie używa podobnych zabiegów literackich, konstruujących wrażenie podobnej nieopanowanej emocjonalności, rozlewnej i rytmicznej, pełnej przymusu powtarzalności ${ }^{29}$. Gdy jednak spojrzymy na cały tekst Morfiny, nie sposób nie dostrzec, że jest to jednak proza męska, pełna zresztą stereotypowo męskich, wojennych i erotycznych atrybutów, którym mógłby patronować Witkacy jako autor Pożegnania jesieni ${ }^{30}$. Równocześnie jednak posiada ona niemal wszystkie, cechy języka kobiecego, które można odczytać z tekstów teoretycznych i odnieść do poetyki tekstu, takie jak: fragmentaryczność, brak linearności i ciągów przyczynowo-skutkowych, kompulsywność wypowiedzi, emocjonalność, zmysłowość, powtórzenia i wyliczenia, poetyckie ekwiwalenty stanów wewnętrznych, skłonność do dygresji i swobodnych skojarzeń, poetyckie tropy, subiektywność i cielesność. Nie sposób jednak uznać, że to proza „kobieca”, co dobitnie pokazuje, iż „kobiecość” tekstu wykracza poza granice poetyki. Zapewne dlatego tak trudno jest zdefiniować język kobiecy. Wymarzony przez Hélène Cixous język kobiecego ciała okazał się pięknym złudzeniem. Kobiety mają do dyspozycji ten sam system znaków, co mężczyźni i wbrew marzeniom drugiej fali feminizmu, ich fizjologia nie jest w stanie tworzyć nowych, odmiennych struktur dostępnych wyłącznie dla nich i wypływających z ich biologicznej odmienności. Nie oznacza to jednak, że używanie podobnych

pl/1,76842,14601973,Polska_meskosc_ciemnosc___Morfina_Szczepana_Twardocha.html [dostęp: 13.02.2017]; z kolei dla Damiana Piwowarczyka z portalu Culture.pl może to też być śmierć, rozpacz albo Polska, http://culture.pl/pl/dzielo/szczepan-twardoch-morfina [dostęp: 13.02.2017]; przykłady można mnożyć.

${ }^{28}$ S. Twardoch, Morfina, s. 389-390.

${ }^{29}$ Por. J. Bargielska, Obsoletki.

${ }^{30}$ Por. S.I. Witkiewicz, Pożegnanie jesieni, Warszawa 1983. 
strategii językowych przez autorów obu płci daje ten sam rezultat. Niewątpliwie $\mathrm{w}$ podziale twórczości na męską i kobiecą istnieje nieredukowalny element odmiennego postrzegania świata, pewien trudno uchwytny, ale zaznaczający swoją obecność wyróżnik innej percepcji w zależności od płci. Nie ma jednak osobnego języka, a próby podziału na męskie i kobiece pisarstwo bądź na „męskie" i ,niemęskie” pisarki przynoszą ryzykowne skutki. Taki podział, polegający na afirmacji histerii jako wyróżnika twórczości autorek, przyczynia się bowiem do utrwalania stereotypu. I nawet jeśli próbuje uczynić z niego subwersywną siłę - umacnia najstarsze, krzywdzące schematy mówiące o kobietach jako nieracjonalnych i nieumiejących zapanować nad własną emocjonalnością. Z kolei określanie „kobiecego” stylu pisania w taki sposób, jak robi to Grażyna Borkowska, wydaje się niezamierzenie wykluczające, bo nazywając twórczość męską pisarstwem kobiecym, badaczka odbiera mężczyznom prawo do autonomicznej, własnej emocjonalności czy choćby histeryczności. Podporządkowując cechy pisarstwa męskiego według stereotypu, co męskie może być, a co nie, Borkowska wyklucza na przykład sfery męskiej histerii jako nieodpowiednie dla tej płci i utrzymuje dawno już podważony podział na proste opozycje binarne.

„Pisarstwo kobiece”, wywrotowy potencjał w ciele kobiety i w jej histerii, odnajdywanie cech żeńskich w pisarstwie mężczyzn - to wszystko było potrzebne na pewnym etapie emancypacji autorek i autorów. Wiele się jednak od narodzin tych projektów zmieniło, także w postrzeganiu męskiej emocjonalności. Również pisarze otwierają się dziś na pewne nielinearne, kompulsywne style pisania i okazuje się, że w nich również tkwią pokłady takiej emocjonalności. Kobiety pisarki z kolei udowadniają, że tzw. kobiecy język nie jest jedynym, którym potrafią się posługiwać. Przyglądając się różnym narracjom obu płci z tej perspektywy, odnoszę wrażenie, że klasyfikowanie prozy na męską i kobiecą nie jest odpowiedzialnym, naukowym sposobem myślenia, gdyż nie ma żadnych niepodważalnych wyróżników w języku czy narracji, które mogłyby takie rozróżnienie udowodnić.

\section{Bibliografia}

Beauvoir de S., Druga płeć, przeł. G. Mycielska, M. Leśniewska, Warszawa 2014.

Borkowska G., Metafora drożdży. Co to jest literatura/poezja kobieca [w:] Ciało i tekst. Feminizm w literaturoznawstwie - antologia szkiców, red. A. Nasiłowska, Warszawa 2001.

Cixous H., Śmiech meduzy, przeł. A. Nasiłowska „Teksty Drugie” 1993, nr 4-6.

Dybel P., Histeria - , inny język” kobiecości?, ,Teksty Drugie” 2006, nr 6.

Irigaray L., Ta płeć (jedna) płcia niebędąca, przeł. S. Królak, Kraków 2010. 
Kłosińska K., Ciało, pożądanie, ubranie. O wczesnych powieściach Gabrieli Zapolskiej, Kraków 1999.

Krzywicka I., Jazgot niewieści, czyli przerost stylu [w:] „,Chamuly”, „,gnidy”, „przemilczacze"... Antologia dwudziestowiecznego pamfletu polskiego, oprac. D. Kozicka, Kraków 2011.

Majbroda K., Feministyczna krytyka literatury w Polsce po 1989 roku. Tekst, dyskurs, poznanie z odmiennej perspektywy, Kraków 2012.

Miller N.K., Arachnologie: kobieta, tekst i krytyka, przeł. K. Kłosińska, K. Kłosiński [w:] Teorie literatury XX wieku. Antologia, red. A. Burzyńska, M.P. Markowski, Kraków 2007.

Piwowarczyk D., Szczepan Twardoch, ,,Morfina”, http://culture.pl/pl/dzielo/szczepan-twardoch-morfina [dostęp: 13.02.2017].

Showalter E., Przedstawiając Ofelię. Kobiety, szaleństwo i zadania krytyki feministycznej [w:] Ciało i tekst. Feminizm w literaturoznawstwie - antologia szkiców, red. A. Nasiłowska, Warszawa 2001.

Sobolewska J., Mężczyzna w rękach kobiet, http://www.polityka.pl/tygodnikpolityka/kultura/ksiazki/1533239,1, recenzja-ksiazki-szczepan-twardoch-morfina.read [dostęp: 13.02.2017].

Sobolewska J., Polska, męskość, ciemność - „,Morfina” Szczepana Twardocha w finale Nike, http://wyborcza.pl/1,76842,14601973,Polska_meskosc_ciemnosc Morfina_Szczepana_Twardocha.html [dostęp: 13.02.2017].

Świerkosz M., Arachne i Atena. W stronę innej poetyki pisarstwa kobiecego, „Teksty Drugie" 2015, nr 6.

Tabaszewska J., Zepsuty afekt [w:] Ciała zdruzgotane, ciała oporne. Afektywne lektury XX wieku, red. A. Lipszyc, M. Zaleski, Warszawa 2015.

Topolewski J., Rozbić triadę. Histeria, kobiecość, feminizm - wedlug Elaine Showalter [w:] Krytyka feministyczna. Siostra teorii i historii literatury, red. G. Borkowska, L. Sikorska, Warszawa 2000.

Wróbel A., ,,Rozhisteryzowany swoją niemocą” - męskość w twórczości Tadeusza Konwickiego (na podstawie „, Sennika wspótczesnego”), „Teksty Drugie” 2015, nr 2. 